\title{
CABRAL APORTA EM PORTUGAL: POESIA BRASILEIRA LIDA PELA CRÍTICA PORTUGUESA ATUAL
}

\author{
CABRAL DOCKS IN PORTUGAL: \\ BRAZILIAN POETRY READ BY \\ CURRENT PORTUGUESE CRITICISM
}

Viviana Bosi*

\begin{abstract}
RESUMO
Pretendemos comentar leituras realizadas pela crítica portuguesa atual acerca da poesia brasileira moderna, enfocando, no âmbito deste artigo, ensaios recentes sobre João Cabral de Melo Neto. Na introdução, fazemos um breve apanhado sobre a situação do ensino da literatura brasileira em Portugal hoje.
\end{abstract}

PALAVRAS-CHAVE: crítica portuguesa atual; poesia brasileira moderna; João Cabral de Melo Neto.

\section{ABSTRACT}

We intend to comment some literary studies written by current Portuguese critics regarding modern Brazilian poetry, focusing in recent essays about João Cabral de Melo Neto. In the beginning, we make a brief presentation about Brazilian literary studies in Portugal nowadays.

KEYWORDS: Portuguese criticismo; modern Brazilian poetry; João Cabral de Melo Neto. 
Há um contar de si no escolher,

no buscar-se entre o que dos outros,

entre o que outros disseram

(João Cabral de Melo Neto. "Para Selden Rodman, antologista". Museu de tudo)

Entretanto cada um deve beber no coração do outro.

Todos somos amassados, triturados:

O outro deve nos ajudar a reconstituir nossa forma.

[...]

Procuras alguém que seja obscuro e mínimo

Que possa de novo te apresentar a ti mesmo.

(Murilo Mendes, “O rato e a comunidade”. Poesia Liberdade)

Nosso intento geral consiste em verificar como a crítica portuguesa atual lê a poesia brasileira moderna, tendo em vista parâmetros tanto de sua herança poética quanto de seu diálogo com a crítica brasileira. ${ }^{2}$

Trata-se, pois, de um exercício discreto de "metacrítica", na expressão de Eduardo Lourenço, o qual avalia que ninguém consegue tornar-se um crítico sem anteriormente entrar em contato com outros que o tenham sido antes dele:

Não é impensável mas é pouco crível que um pensamento crítico ou, mais pretensiosamente, uma poética, nasçam do puro contato suscitado pela obra de arte. Naturalmente, que não podem nascer sem ele, mas o que sucede sempre é que o aprendiz de crítico descobre a sua vocação no contato de outra interpretação encontrada no seu caminho, diante da qual se entusiasma ou indigna e o que o incita ao eterno "anche io sono pittore". (LOURENÇO, 1974, p. 12).

Conhecer a forma como intérpretes qualificados, de uma cultura semelhante (mas não igual) à brasileira, leem a nossa poesia, expande a câmara de ressonância e de compreensão desta, ao contemplar outras focalizações.

Críticos e poetas (ou poetas-críticos) portugueses consagrados escreveram, no passado, estudos importantes sobre poesia brasileira. ${ }^{3}$ Mas hoje, é de se notar o encolhimento crescente dos envolvidos com o ensino e a pesquisa da literatura brasileira em Portugal. Desde a Declaração de Bolonha (que começou a ser implantada na virada do século), as universidades europeias passam por um processo de "racionalização" de gastos que incide de forma especialmente danosa sobre as humanidades. $\mathrm{O}$ fato de os cursos de Letras terem diminuído seu tempo de duração para três anos em todos os países integrantes da União Europeia, aliado à condição de precisarem obter um número mínimo de alunos para serem declarados sustentáveis, e tudo isso agravado pela crise econômica que se desencadeou duramente sobre alguns desses países desde 2008, resultou, como sequela, na não reposição de docentes que se aposentaram, muitos deles açodados 
pelo temor de perder direitos ou mesmo inconformados com o estado presente da universidade. Com isso, o ensino regular de literatura brasileira restringe-se, no geral, a apenas um ou dois semestres dos cursos de Letras, o mais das vezes optativos, quando os há. Na maioria dos casos, o professor acumula outros cursos de literatura comparada, africana ou hispânica. Ou ainda, ensina literatura brasileira junto às demais literaturas e culturas lusófonas. Uma consequência adicional da criação de um "espaço europeu" de ensino universitário foi a concentração de interesses à volta da cultura europeia, em sua variedade e riqueza, o que trouxe benefícios para a formação dos estudantes locais, hoje mais cosmopolitas, mas afastou-os ainda mais do Brasil, agora distante. De forma que uma tradição de estudos que nunca constituiu-se com grande realce, estaria a ponto de perder-se completamente, não fosse a disposição de uma nova geração de críticos de mantê-la viva graças a seus interesses pessoais de leitores envolvidos com a poesia em língua portuguesa de modo amplo.

Tanto Eduardo Lourenço (em A nau de Ícaro, 2001) quanto Abel Barros Baptista, em seu ensaio "Ensinar literatura brasileira em Portugal" (que encima o programa de curso por ele proposto em seu $O$ livro agreste: ensaio de curso de literatura brasileira, 2005) concordam quanto à pouca relevância conferida à literatura brasileira nas faculdades de Letras portuguesas, julgada menor em comparação a outras mais estabelecidas, geralmente europeias. O movimento de exclusão e autonomização mútuas entre Brasil e Portugal, que foi se processando durante a formação do país novo como nação, com rupturas culturais, linguísticas, sociais, gera equívocos de compreensão de parte a parte. Dignas de referência nesta seara são as pesquisas abrangentes de Arnaldo Saraiva (2004) sobre as "convergências, divergências" dos "brasilófobos" e "brasilófilos" em Portugal (e vice-versa, no Brasil: "lusófobos" e "lusófilos") ao longo das nossas relações culturais por vezes tensas, por vezes cordiais.

Ida Alves confirma esse diagnóstico ao examinar o diálogo existente entre as poéticas e críticas de poesia dos dois países. Constata que havia uma leitura consistente e produtiva da poesia brasileira entre os poetas e críticos portugueses até os anos 60, mas conclui: "Os primeiros resultados demonstram muito claramente os enlaces entre a poesia portuguesa e a brasileira, principalmente nas décadas de 50 e 60 com progressivo e, já agora, ostensivo silêncio a partir da década de 70.” (ALVES, 2003).

Apesar desta rarefação, as gerações agora atuantes nas universidades portuguesas continuam, ainda que em menor grau, a debruçar-se sobre a poesia brasileira com resultados estimulantes, em especial relativamente a alguns nomes de maior vulto como Drummond, Cabral, Cecília Meireles. Já os contemporâneos recebem atenção esparsa e pontual.

Dadas as dimensões restritas deste espaço, enfocaremos, a partir de agora, um conjunto de ensaios à volta de João Cabral de Melo Neto o qual, pelo que se observou, é um dos poetas melhor estudados pela críti- 
ca portuguesa. Foi necessário, e acabou por representar nosso principal procedimento, efetuar paráfrases sintéticas de cada trabalho selecionado a fim de tentar retratá-lo, valendo-me de descrições resumidas dos tópicos principais, de modo a procurar não distorcer o fio do raciocínio que o guia. Apenas a partir desse exercício poder-se-ia envidar uma seleção das ideias mais relevantes. Esperamos que tal não resulte numa leitura excessivamente enfadonha, mesmo que sua proposta seja manter-se rente ao material lido, dele removendo, infelizmente, o sumo e a vivacidade do estilo, uma vez que apenas os andaimes principais foram destacados. Tal limitação é bem delicada quando se trata de buscar reproduzir as ideias centrais de ensaios cuja linguagem segue de perto a complexidade metafórica de um texto literário, dado que o nosso propósito resume-se a tão-somente explicitar parte substancial do esqueleto lógico ou de possíveis aspectos controversos que sustêm o desenvolvimento do conteúdo.

$\mathrm{Na}$ verdade, trata-se sobretudo de um exercício de admiração, à medida que não nos colocamos numa posição especialmente crítica em relação aos textos, dada a nossa aderência às reflexões neles enunciadas. Seria diferente se o tema fosse controverso, tal como ocorre, por exemplo, em algumas interpretações portuguesas polêmicas acerca do nosso modernismo...

\section{VARIAÇÕES SOBRE CABRAL}

Os estudos sobre o poeta pernambucano contam com respeitável linhagem em Portugal. Desde a primeira publicação dos Poemas escolhidos - seleção de Alexandre O’Neill, com prefácio de Alexandre Pinheiro Torres (1963) - até o sempre referido prefácio de Óscar Lopes, "Das coisas e do seu avesso (sobre a poética de Melo Neto)” à Poesia completa (1986), marco crítico incontornável, consolidou-se um círculo de leitores agudos e antenados, capazes de absorver as discussões da linhagem interpretativa brasileira enquanto formulam uma vertente própria de reflexões.

Conhecemos a afinidade entre Cabral e Sophia de Mello Breyner Andresen, a quem o brasileiro dedicou um poema - "Elogio da usina e de Sofia de Melo Breiner Andresen”, A educação pela pedra (1966) -, ao passo que ela, por sua vez, havia composto um livro inteiramente deduzido de conversas com o brasileiro - O Cristo cigano (1959) -, com poema-dedicatória e imitação do estilo de Cabral, em franca homenagem; e por fim, escreveu um artigo notável sobre sua poesia em 1960 - conforme mencionado na apresentação de Rosa Maria Martelo para a nova edição de $O$ Cristo cigano (2014). ${ }^{4}$

Neste supracitado prefácio à reedição do livro de Sophia, Martelo evoca as qualidades que a poeta portuguesa reconhecia em Cabral e que ambos partilhavam: "rigor", "clareza", "contenção"; "O Cristo cigano nasce do encontro cúmplice entre dois poetas do concreto, da disciplina e da 'rente e justa agudeza'” (MARTELO, 2014, p. 21). 
Mas, para além destas características bem conhecidas, pondera ainda, Sophia também admirava o inesperado e o informe como integrantes do mundo da vida. Por isso, consegue captar, na poética de Cabral, "Algo que às vezes se alucina/ Pois há nessa tão exacta/ Fidelidade à imanência/ Secretas luas ferozes/ Quebrando sóis de evidência.", conforme declara na dedicatória para a segunda edição - pois, como avalia a ensaista ao reproduzir estes versos, "a forma luta por integrar" (op. cit., 2014, p. 21), pela arte, essas tensões.

Assim, a leitura da poesia de Sophia parece ser o parâmetro secreto ou explícito dos críticos portugueses para a apreciação de João Cabral, como uma sombra ou rastro que propicia a aproximação.

Selecionamos, à volta do poeta brasileiro, estudos relativamente recentes que consideramos particularmente relevantes.

A referida Rosa Maria Martelo escreveu vários textos críticos sobre Cabral, desde sua dissertação de mestrado posteriormente publicada em formato de livro (1990). No entanto, recomenda que nos debrucemos em especial sobre o seu ensaio mais atual que, segundo a própria, sintetiza de forma satisfatória os trabalhos prévios. Assim, dedicaremos nossa atenção a este "João Cabral de Melo Neto. O poema como amostra de mundo" que integra o volume $A$ forma informe (2010), tendo sido publicado primeiro na revista Colóquio/Letras n. 157-158 (julho-dezembro 2000), em número especificamente dedicado ao poeta, ${ }^{5}$ com um título ligeiramente diferente ("Amostras de mundo: uma leitura goodmaniana de João Cabral de Melo Neto"6).

A crítica começa por anunciar a capacidade de Cabral de "dar a ver" no sentido de apresentar "coisas" para o leitor, advertindo, porém, que "esta poesia não procura produzir qualquer efeito de tipo realista, e que a rugosidade espessa da sua dicção tem uma finalidade clara: impedi-los [os leitores] de cair numa ilusão de transparência da linguagem" (MARTELO, 2010 , p. 49). Tal cautela parece ser dominante na crítica portuguesa contemporânea: sempre cuidar em esclarecer que mimese não é cópia. Talvez algum excesso neorrealista tenha conduzido a reforçarem esse tópico argumentativo.

Mas o centro da especulação de Martelo baseia-se no conceito de Nelson Goodman de exemplificação. Para o filósofo cognitivista, a exemplificação é um processo de referência, uma forma de estabelecer relações de amostragem entre coisas, colocando em relevo algumas das propriedades ou qualidades do objeto a ser evidenciado.

A seguir, a ensaísta ressalta, a respeito da antologia Poesia crítica, publicada por Cabral em 1982, que, embora o poeta tenha distinguido, na sua obra, o que qualificava como uma poesia que acentuava seu pendor para a reflexão sobre a linguagem, nem por isso deixa de tratar de "qualquer coisa" ou abandona a transitividade comunicativa. Mesmo encarecendo o 
rigor e a disciplina compositiva, o resultado nunca deveria ser hermético, ou apenas voltado para si mesmo em metalinguagem. A "realidade pesada" e o trabalho poético estão imbricados um no outro.

Dessa forma, quando o poeta apõe etiquetas de exemplificação, estas correspondem a algumas propriedades às quais ele irá se referir tanto por imagens quanto na própria estrutura do poema. São elas, segundo Martelo, tensão, contenção, exatidão... que podem ter como protótipo a faca, que comparece no poema como sinônimo de agudeza e limpeza, no que se refere à sua construção "despojada”, em oposição ao que Cabral rejeita (o "lirismo torrencial e espontaneísta, que pejorativamente designa pela palavra 'diarréia”', op. cit., p. 57).

De modo que, conclui a autora, essa pobreza de meios que ele defende tanto se dirige aos temas quanto à construção do poema, gerando um "profundíssimo adensamento de sentido" (idem, p. 50). O seu "despojamento discursivo", através do qual recusa a fluência musical e certa retórica mais exuberante, filia-se, de acordo com sua leitura, ora ao tipo de paisagem nordestina seca ora a um rio pantanoso e monótono como o Capiberibe. Sua linguagem vai exprimir, então, a falta, a fome, as "coisas do não" através de "sua carnadura concreta', o 'seu adensar-se compacta" (idem, p. 60).

Outro tópico que Martelo irá sublinhar em seu ensaio, articulado ao que acabamos de resumir, será o aspecto notadamente visual da poesia de Cabral: ele escreve "porque vê e para ver e dar a ver" (ibidem, p. 60). Sem a vista, quase cego no final da vida, nega-se portanto a escrever, já que o poema depende totalmente de se tornar perceptível e visível no espaço. As palavras básicas que o compõe são substantivos bastante concretos, que podem ser visualizados mentalmente com facilidade (pedra, osso, cana, faca, bala, esqueleto, etc), vinculados de forma metafórica, entre o familiar e o estranhamento.

Ainda sob o domínio dos conceitos de Goodman, a crítica escolhe apreciar uma das imagens fortes de Cabral, o canavial, que em sua poesia é por vezes associado ao mar, em sua regularidade, extensão e ondulação. Ela expõe o processo de coexemplificação que emparelha, por determinadas qualidades perceptivas, canavial e mar. Já quando o canavial é açoitado pelo vento, o poeta compara-o aos movimentos do povo lutando na praça, de modo que oferece novas relações para o leitor apreender o real.

Trata-se, portanto, de um "processo de re-conhecimento do mundo no qual o texto e as coisas partilham um mesmo tipo de funcionamento exemplificativo, isto é, um processo de referência que não se confunde com a noção de representação." Não que esta esteja excluída, mas o que importa é demonstrar uma forma de funcionamento em que cada coisa, e até mesmo o próprio poema, é uma amostra "desse mundo que a poesia de João Cabral procura desnudar e compreender.” (ibidem, p. 70). 
O que nos parece original no ensaio de Rosa Maria Martelo é esta súbita inversão: não se trata de subordinar o poema à descrição das coisas, mas ao contrário, escolher coisas que sejam representativas de uma linguagem, de uma sintaxe, que delimitaria um mundo a ser então figurado.

Talvez isto seja exemplarmente claro em Cabral, embora característico, de modo difuso e menos explícito, em outros poetas que não disporiam de foco tão demarcado.

Esta revista Colóquio Letras dedicada a Cabral (julho-dezembro 2000) contém ainda um ensaio de Joana Matos Frias intitulado "Um olhar nítido como um girassol: João Cabral e Murilo Mendes"?

Neste, Frias reitera a primazia do olhar na poesia do pernambucano, a partir de uma entrevista muito citada, em que Cabral atribui a $\mathrm{Mu}$ rilo Mendes o ter aprendido "a importância do visual sobre o conceitual, do plástico sobre o musical”, mesmo pesadas as diferenças entre ambos: "Sua poesia me ensinou que a palavra concreta, porque sensorial, é sempre mais poética do que a palavra abstracta, e que assim a função do poeta é dar a ver (a cheirar, a tocar, a provar, de certa forma a ouvir: enfim, a sentir) o que ele quer dizer, isto é, dar a pensar." (NETO apud FRIAS, 2000, p. 63)

(Reproduzo estas palavras famosas do poeta porque elas parecem estabelecer um alicerce de leitura à volta do qual circulam os artigos críticos sobre ele que li em Portugal.)

Acrescenta a estudiosa que o "olho armado" de Murilo, aliado à inclinação surrealista que, nem por isso, abandona o aspecto construtivo, mais o "incessante vaivém entre o abstracto e o concreto" (op. cit., p. 64), exerceram forte influência sobre os primeiros livros do poeta mais jovem, em seu anseio por clareza. No amigo, Cabral divisava o "encontro da lucidez construtiva do cubismo com a ilogicidade onírica do surrealismo", refletira José Paulo Paes (PAES apud FRIAS, 2000, p. 65). Mas Cabral irá paulatinamente abandonando o segundo termo da equação (a vertente onírica) para alcançar uma "afirmação crescente de um híper-realismo de índole imagista" e, a acreditar no próprio Murilo (e assim como ele), tendo sempre renegado a escrita automática inspirada em prol do trabalho compositivo.

A relação próxima entre poesia e pintura será compartilhada pelos dois poetas, demonstra Frias, mas em Cabral não será o surrealismo a vertente dominante, e sim o cubismo, através do qual conceberá uma "visão polifónica do objeto decomposto e em movimento, confluindo os valores da profundidade, da densidade e da duração numa poesia altamente estereodinâmica." (idem, p. 67). Poema paradigmático desse procedimento, "Estudos para uma bailadora andaluza" (Quaderna), assemelha-se, segundo a estudiosa, a um "quadro dançante", à imagem em movimento, ao proporcionar uma "deslocação sucessiva do ângulo de visão do sujeito em torno do objeto" (ibidem, p. 68). O cinema sempre exerceu atração sobre ambos, mas, enquanto Murilo era fascinado pela montagem, à la Eisens- 
tein (dado o seu pendor para a contradição dialética), Cabral pende para o olho-câmara, que segue o objeto em vários ângulos, em zooms e travellings, transitando, em alguns poemas, do concreto para o abstrato geométrico, do próximo para o distante.

Este amor à concretude e às formas essenciais localiza na literatura espanhola seu avatar, tanto para Cabral quanto para Murilo, matizando o surrealismo inicial. Mas, reflete a autora, deve-se advertir que a poesia de Cabral oscila entre o dar a ver e o dar a pensar, "entre a imagem e o conceito", como se, de um lado, enfatizasse, através do descritivismo, o desejo de apreender a coisa em seu gume, e de outro, a impossibilidade de apanhar realmente a coisa através da palavra.

Como se percebe, parece haver uma linha de continuidade entre as conclusões de Martelo e de Frias, seja quanto à tendência plástica na poesia de Cabral, seja quanto à síntese intelectual que constrói, a transfigurar o meramente mimético.

Concentrada, ainda, neste excelente número da Colóquio, anoto brevemente a análise interpretativa do poema "O hospital da caatinga" - $A$ educação pela pedra (1966) - elaborada por Abel Barros Baptista em seu ensaio "A ortopedia do símile". Nele, o crítico atenta para o contraste entre a primeira e a segunda parte do poema, no qual o símile proposto entre caatinga e hospital se repropõe, mas praticamente invertendo-se. Não mais a figura do deserto, "nu asséptico"; ao contrário, a "superpovoada" "clínica ortopédica" na qual se combinam "o esquelético/ e o atrofiado, com o informe e o torto". A segunda estrofe contesta assim a primeira, utilizando-se da "paralipse" (figura retórica pela qual se finge não querer tratar de um assunto, embora vá se falando dele, segundo a definição do dicionário). O crítico constata como, de certo modo, esse "estilo/ com seu aleijão poliforme" parece repudiar o mero minimalismo do seco limpo como figura dominante de sua poesia, ao qual normalmente Cabral é confinado pelos seus leitores. Assim, as duas águas se confundem, superpondo paisagem e reflexão metapoética.

Esta análise procura alargar e mesmo contradizer uma forma estática de ler Cabral, ao propor um fulcro perturbador de tensões.

Ao redor deste denso núcleo de estudos cabralinos, registramos dois ensaios de Carlos Mendes de Sousa que também dilatam o âmbito de interpretações da obra do poeta.

O primeiro, "João Cabral, ou o poema como epitáfio", foi publicado na revista Inimigo Rumor n. 14 (1º. Sem. de 2003).

O crítico percute, em baixo contínuo, a ideia de que não se pode traçar uma imagem enrijecida da obra cabralina, mas abraçar, ao invés, a concepção da deriva, que desvia o olhar de certa leitura canônica e evita um "eixo estabilizador" ou apaziguador, por vezes propagado inclusive pelo próprio poeta, seja ao apartar as "duas águas", seja ao recusar inteira- 
mente o seu aspecto autobiográfico, e ainda ao reforçar o preconceito contra a música, como se não houvesse uma melodia própria à sua poesia. Para Sousa, são as "zonas de tensão" as que fortalecem a tessitura da obra. De novo, alude ao poema-dedicatória de Sophia, com sua referência à loucura, à alucinação, que subjazeria a lucidez construtiva de Cabral.

Segundo o estudioso, dois temas entrelaçados convergem para delinear uma figura do poeta: a viagem e a morte, como "cerne da própria experiência da escrita" (SOUSA, 2003, p. 157). Conforme depreende, os percursos de viagem, em poemas extensos como "Morte e vida severina" ou "O Rio", desembocam na morte. O número de poemas sobre cemitérios revelaria muito de sua fixação por habitar espaços antilíricos, secos, em que se depara com as mortes injustas e anônimas do lavrador pobre, que no enterro se iguala à terra de onde veio. $\mathrm{O}$ temor de encarar a própria morte congrega-se à figuração da morte social, que o poeta focaliza.

Ao mesmo tempo, defende Sousa, o motivo do caminhar, até mesmo como metáfora da poesia, persegue-o até Sevilha andando. Um substrato biográfico acompanharia essa poesia de paisagens de um poeta itinerante. Cabral, em sua obra, confere um rosto próprio aos lugares de exílio, numa dialética de desterro e convergência. Se há forças de abertura e dispersão, próprias desses trajetos, há, ao mesmo tempo, forças de contenção, seja na forma, tão regular, seja nessa capacidade de transformar a nova terra num símile de suas obsessões, gerando uma "arquitectura inquieta" (op. cit., 2003, p. 162).

Assim, para o crítico, se a poesia de Cabral filia-se a qualidades solares, de claridade, todavia deve-se atentar para o resíduo, pois a pulsão de morte convive com a luz do meio-dia. E ainda, especula, o que o poema tão objetivamente expõe, é, em parte, este sujeito que nele se projeta:

A figura biográfica indirectamente torna-se central, de tal modo que a imagem do eu poético passa a ser coincidente com a imagem da poesia. $\mathrm{O}$ sujeito poético está no centro da obra. Não no sentido da unidade procurada pelos românticos, mas na tensão mesma entre esse propósito despersonalizador e a configuração unitária em que a presença do eu é subliminarmente obsessiva. (idem, p. 167)

Viagem e morte, luz e cemitérios, sujeito singular ou anônimos populares... todas essas imagens acabam por configurar uma persona peculiar.

O ensaísta conclui com a transcrição da primeira estrofe de "Num monumento à aspirina", sugerindo que tanto os poemas sobre a "dor de seres anónimos" quanto aqueles que se referem aos objetos mais díspares estão carregados do pathos do epitáfio do próprio poeta, e condensam a tensão do dia claro que contém a aniquilação.

Em seguida, voltamo-nos para o seu posfácio à obra $A$ educação pela pedra (de 1966, reeditada em Portugal em 2006), intitulado "Dar a ver o poema". 
Levando em consideração o público português, Carlos Mendes de Sousa nomeia as principais características de João Cabral, tais como sobejamente estudadas pela crítica brasileira, de modo bastante ilustrativo e claro, com a seriedade de pesquisador consciente que procura abordar o máximo de aspectos de uma poética. Elenco alguns destes tópicos, devidamente elaborados no texto e aqui apenas esboçados:

- “a presença obsessiva do Nordeste brasileiro” (p. 120)

- "títulos que reenviam para a esfera das artes plásticas" (p. 120)

- a especial "enfatização da 'tendência construtivista" (p. 121)

- "consciência crítica do poeta em relação ao sistema literário" e do seu lugar "em termos de enquadramento histórico" (p. 121)

- "o recurso a dispositivos pouco usuais na tradição retórico-estilística luso-brasileira (em relação à qual se coloca como um "marginal", pois nela não se reconhece), quando confessa a preferência por esquemas métricos menos comuns, "assim como a utilização preferencial da rima toante, mais corrente na tradição espanhola.” (p. 122)

- a investida do poeta contra o que reputa como facilidade formal no Auto de Natal pernambucano, em entrevista concedida ao Diário de Lisboa (16/06/1966), quando da apresentação em Portugal de "Morte e vida severina", musicada por Chico Buarque. (Porém, mais tarde, assume que compusera este longo poema de modo propositadamente simples, imitando em parte o cordel e o romanceiro popular, para que fosse compreendido por um público mais amplo.)

Sousa discorda da partição, à época corrente (pois difundida pelo próprio Cabral), e afirma que "Existe uma natural complementação de sentidos, tornando-se evidente, da leitura da obra, a impossibilidade da divisão das 'duas águas' de uma forma simplista e esquemática.” (op. cit., 2006, p. 124)

- o travo exigente de autocrítica, que se perpetua ao longo da trajetória do poeta, em permanente "inquieto desconforto de quem continua insatisfeito a problematizar a própria arte." (p. 125).

- frisa ainda a importância da pedra, em suas palavras, "uma lição entranhada: a da imanência do sertão", "a afirmação veemente de uma dicção e de uma ética - uma educação para uma poética do rigor, da concisão e da justeza" (p. 128) que, desde uma das leituras críticas inaugurais de sua poesia, é sempre realçada ("A estética, em outras palavras, assentava sobre uma ética", já assinalara Sérgio Buarque de Hollanda, nos anos 50, tal como citado no texto, à página 143).

Um momento mais pessoal do posfácio ocorre quando se refere ao hábito do escritor Autran Dourado de reler todo ano romances de Machado de Assis para "lavar a língua" que fica "suja" pela saturação de obras menores. O ensaísta português compartilha desse sentimento em relação à obra de Cabral, que teria uma "função pedagógica" e atuaria como "lição 
para poetas", "modelo" que "acaba por repercutir fortemente na literatura brasileira" (op. cit., p. 126-127).

Outra hipótese, já adiantada em seu outro texto (mencionado acima), propõe a centralidade da voz do poeta, que acaba por revelar um rosto muito próprio a despeito da apregoada impessoalidade da máquina do poema...

Ademais, analisa com minúcia a composição altamente estruturada de $A$ educação pela pedra, cuja arquitetura consciente esta publicação portuguesa revela, ao respeitar a diagramação original da primeira edição, fato que as edições brasileiras posteriores tendem a ignorar. A "sintaxe visual" do livro foi organizada, segundo observa, de acordo com uma sequência que leva em conta temas, divisões e tamanhos, colocando lado a lado estrofes simétricas e equivalentes, cujo assunto pode ser complementar ou até oposto. Sousa detém-se, igualmente, sobre uma "apresentação da planta do livro", tal como planejada por João Cabral, publicada na revista Colóquio/Letras 157-158 (julho-dezembro 2000) por Antonio Carlos Secchin, o qual expunha os mecanismos rigorosos de construção deste volume que, conforme lamentava, "desapareceu, ou foi sensivelmente adulterada por alegada economia de custos de produção, em todas as edições posteriores" (SECCHIN, 2000, p. 159). Sem reproduzirmos aqui a sua atenta explanação, embasada em estudos críticos anteriores, o "relevo [à] dimensão gráfico-visual” (SOUSA, 2006, p. 131) concedido à presente edição participa do cuidado deste trabalho crítico português, graças, provavelmente, às pesquisas sobre a materialidade na poesia realizados na Universidade de Coimbra, de cuja equipe de investigação pertence o mentor desta coleção de literatura brasileira, Abel Barros Baptista. ${ }^{8}$

O crítico coloca em questão um suposto realismo na descrição da paisagem e do homem em Cabral, uma vez que, diferentemente do romance dito regionalista, aqui a "invenção verbal" remete ao universo nordestino, mas transforma-o em "paisagem-língua" (como o batiza Sousa), criando um jogo de homologias imagéticas e sonoras entre ambos. De acordo com o estudioso, "As ausências rememoradas são captadas pelo trânsito da apropriação que suspende o lugar e o transforma em tropo, em paisagem retórica (ars faciendi)." (op. cit., p. 139). (De certa maneira, ele retoma o que Rosa Maria Martelo já havia abordado.)

Por fim, desdobra o tópico que dá nome a seu ensaio: "o absoluto primado da visualidade e da espacialidade" (idem, p. 141) na poética de Cabral. Todo o processo de cognição do mundo e de subsequente criação advém do olhar. O próprio método de composição do poema assemelha-se à construção espacial arquitetônica, e os seus motivos são, no geral, relacionados ao concreto da casa, da paisagem, da cidade... (Aqui também, é relevante a coincidência com a posição de Martelo e Frias que acabamos de abordar). 
E, para terminar a síntese simplificada das linhas principais deste posfácio tão rico, o autor remete a uma discussão que transparecia no texto de apresentação de Rosa Maria Martelo sobre O Cristo cigano, de Sophia de Mello Breyner Andresen, evocado acima, mas que Sousa encorpa um pouco mais: a percepção de que, para além das "obsessões que se manifestarão em círculos cada vez mais apertados" (ibidem, p. 148), ao redor dos quais gira o universo poético tão construído de Cabral, estas "ideias fixas" que se concretizam paradigmaticamente nas formas repetidas das quadras ("o esforço de contorno formalizante”, p. 151) testemunham a inquietação de um poeta com "capacidade de arrumar a violência irrefreável dos trânsitos turbulentos" (ibidem, p. 150), isto é, a necessidade de ordem seria equivalente ao grau de penetração de alguém que conhece e enfrenta "a tensiva realidade do mundo marcado pelo ímpar e pelo instável” (ibidem, p. 151).

Embora, como havíamos delimitado em nosso projeto de pesquisa, os professores aposentados não fizessem parte do âmbito de investigação, não podemos omitir a menção ao livro de Maria Andresen de Sousa Tavares, Poesia e pensamento. Wallace Stevens, Francis Ponge, João Cabral de Melo Neto (2001), resultante de sua tese de doutoramento, no qual a estudiosa reúne os três poetas (sem deixar de acentuar a singularidade de cada um e as diferenças entre eles), a partir da tendência à objetividade e à busca do mundo das coisas, que lhes é comum.

Um pouco antes desta publicação, a autora redigiu o que seria uma síntese das suas ideias expostas no livro acerca da poética de João Cabral na mesma revista Colóquio (n. 157-158, 2000) em que se concentram os ensaios mencionados acima. De modo que pareceria uma exclusão puramente formal se não nos detivéssemos em seu artigo, "João Cabral de Melo Neto. Razão e serventia das ideias fixas", afinal perfeitamente contemporâneo aos demais aqui coligidos.

Segundo a autora, a dificuldade da escrita em Cabral é proporcional ao esforço para perseguir as coisas que, na sua aspereza, obrigam a uma grande obstinação e rigor para conseguir-se que possam afinal ser postas em palavras no poema. Isto corresponde ao eixo temático em Cabral, que rodeia cada objeto com várias tentativas de apreensão, pelo símile, mesmo consciente da insuficiência e da ausência no resultado final.

O inacabamento do sentido e mesmo do verso, com seu ritmo quebrado, desestabilizado por uma construção que quer romper hábitos fluidos e acomodados, revelando o tosco e o pouco do real, constitui uma de suas "ideias fixas". Cortar, afiar, limpar... são verbos congeniais a esse trabalho obstinado de busca "iluminista" pela "realidade prima", em que as coisas e as falas anônimas poderiam enfim tornar-se visíveis no poema. Mas esta redução contínua até se atingir o cante a palo seco desvela na verdade o vazio, a impossibilidade de apreender o objeto real. Nesse movimento de erguer-se na direção da coisa, porém, reside a sua teimosa e 
difícil finalidade: "cante sem": "O objeto poético, enquanto 'realidade concreta' reduz-se quase à tensão de um ato".

A estudiosa supõe, portanto, que haveria, em Cabral, um duplo impulso, divergente:

Quase poderíamos falar em dois movimentos: o que parece querer tomar pelo domínio da palavra a dicção do mundo e o que faz da ironia a figura dominante no diálogo com o 'real', tomando no seu terreno o próprio gesto solitário, o ato em si. $[\ldots]$

o fazer erguendo-se como ato que funda em si o seu sentido sobre um horizonte de ausência de sentido, desligado, por isso, de qualquer razão maior que o integre (TAVARES, 2000, p. 270).

Não há, nesse fazer engenhoso e lúcido mas incessante, niilismo ou amargura, conclui Tavares... porém, perguntamos nós, a finalidade sem fim, que nunca se perfaz, seria esta criação em série contínua do próprio objeto-poema como processo e resultante?

Passo a comentar, por fim, outro ensaio recente sobre o poeta pernambucano, "Faca partilhada", de Pedro Eiras (2011), no qual o autor compara aspectos das poéticas de Cabral e de Sophia. Novamente, o mote é a reedição do livro O Cristo cigano (1 ${ }^{\text {a }}$. Ed. 1961), deixado, num primeiro momento, à margem das Obras completas da poeta portuguesa por um longo período, pois ela o acreditava devedor demais do estilo de Cabral. ${ }^{9}$

Extraio do texto apenas algumas de suas ideias, sobretudo aquelas em que se detém sobre a obra do brasileiro. Também Eiras explora a fenda que o poeta abre entre o desejo de apanhar o ser da coisa, em sua concretude, de forma nua e objetiva, de um lado, e o fato desse "gume" penetrante consistir, acima de tudo, numa "palavra-faca", e não realmente uma coisa em si. Como se vê, este é de fato um tópico bastante frequentado pela crítica portuguesa: "compreender que o "efeito de realidade" poético nada deve a qualquer ideia de transferência do mundo como informação entre autor e leitor, mas tudo à ideia de revelação." (EIRAS, 2011, p. 4). Nós acabamos de observar esta mesma tecla sendo premida nos textos anteriores sobre o poeta.

Para o crítico, o fato de a poesia não equivaler à mera imitação, mesmo quando promulga estar a dizer o mundo, e sim, sobretudo, à construção, é crucial para a compreensão da poética de ambos. O elogio que Cabral faz a Sophia no poema escrito em sua homenagem segue justamente este argumento, ao afirmar que a usina de versos da poeta não perfaz apenas movimento de ida, como muitos que se contentariam só com o melaço "informe" ou o mascavo "sem corte", mas, como a moenda da cana, vai e vem várias vezes, até alcançar o cristal (do açúcar), que a poeta deriva de seus cristais próprios, luminosos e marítimos (Sophia “desfaz-faz e faz-refaz", assevera o pernambucano). 
Esta qualidade de fazer aparecer o mundo no poema não é apenas uma incisão solar... como poderiam pensar os leitores acostumados a apreciar a clareza, a justeza, de ambos os poetas... Pedro Eiras percebe que o diálogo entre eles permite espreitarem no outro aquilo que não pode ser vislumbrado quando olhado exclusivamente a partir de dentro de si mesmo. Assim, Sophia pode dar a ver, na poética de Cabral, o aspecto "alucinado", dionisíaco, incapturável pelo próprio poeta:

João Cabral reconhece em Sophia a usina, a técnica, a feitura, a poiesis. Sophia reendereça a descrição, pensando a oficina de João Cabral; e nesse instante invoca a noite, com duplo, perturbador efeito: porque João Cabral parece nunca abandonar o aparecer solar das coisas, e porque a própria Sophia não costuma referir essa visão nocturna também imanente. Talvez Sophia possa dizer sobre João Cabral o que ele mesmo não pode dizer sobre si próprio, sob risco de contradição. O poeta brasileiro só pode mostrar a alucinação, não dizê-la: dizer a alucinação, em termos de usina, transformá-la-ia em artefacto técnico dominado. Só de fora, do lugar de Sophia, se pode fazer aparecer o lugar onde o aparecer já não é soberano. Do mesmo modo que a agudização da palavra faca por João Cabral gera O Cristo Cigano, Sophia revela em João Cabral o que $A$ Educação pela Pedra faz mas não pode dizer. (EIRAS, 2011, p. 7)

Talvez Cabral, ao encarecer o trabalho exigente de Sophia, esteja a tratar tanto de si mesmo quanto dela, omitindo o aspecto espontâneo e desconsiderando o anseio pelo imediato que igualmente habita a sua poética.

(Já havíamos reiterado que esta questão fora mencionada pelos outros ensaístas anteriores, mas aqui Eiras lança-lhe nova luz.)

Outra ideia fecunda é a percepção da tensão que a faca simbolizaria - uma fome de coisas, as quais se perseguem com ardor desejando avidamente penetrá-las. Mas estas coisas densas acham-se prontas para rebentar, explodir, ao contato da faca que as procura... como as romãs que em espanhol se chamam granadas (Cabral), ou como os frutos interiormente acesos (Sophia)... algo que nem mora dentro nem fora do poeta... contudo, a disciplina para finalmente alcançá-las de certa forma as torna ainda mais espessas, convertendo-as em sínteses de si mesmas:

As "coisas mais coisas" são as que quase perdem o ser-coisas para devirem pura geometria; mas perder é o grau máximo do ser (tal como o sujeito desaparece para que haja poema) e não nega a existência absoluta da coisa (ela própria recorte negativo no mundo, instauração da diferença). A coisa alcança a geometria não por fugir a ser coisa, mas por ser intensamente coisa. (EIRAS, 2011, p. 16) 
Assim, a faca passa a ser um instrumento de cognição ontológica, que perfura o real, bem como o esculpe, e, porque corta, faz viver, pois "o que vive fere". Através da arte, o instrumento que mata equivale ao que eterniza um rosto, em analogia com a poesia de ambos os "duelantes", certeira em seu alvo de recortar, configurar, dar a ver.

O texto desdobra ainda outros postulados que não iremos expor, pois o nosso objetivo foi tão-somente delinear alguns aspectos de uma leitura em certa medida diferente das interpretações brasileiras de Cabral, porque o enxerga através de Sophia.

Em suma, a originalidade destes estudos da crítica portuguesa ocorre quando caminham no limite do tensionamento entre razão e "alucinação", ou entre aspectos solares e fixação com a morte, ou ainda, na aproximação ora com a síntese intelectual ordenada do cubismo ora com o disforme e instável, ou afinal entre a despersonalização e as projeções de um rosto e de uma voz próprios - dentre as outras ricas variações assinaladas acima.

Este relato representa apenas uma parte dos estudos cabralinos, os quais integram o rico universo dos trabalhos de pesquisa relativos à poesia brasileira hoje em Portugal. Esperamos, a partir dele, ampliar o intercâmbio com esta comunidade de leitores, pouco conhecida entre nós, e que merece a hospitalidade do convívio com os debates contemporâneos no Brasil.

\section{REFERÊNCIAS BIBLIOGRÁFICAS}

ALVES, Ida Ferreira. "Diálogos e silêncios na poesia portuguesa: décadas de 60 a 90". Revista Letras, Curitiba, Editora UFPR, n. 59, p. 83-92, jan./jun. 2003.

ANDRESEN, Sophia de Mello Breyner. O Cristo cigano. Pref. Rosa Maria Martelo e Nota à 5a. Ed. Maria Andresen de Sousa Tavares. Lisboa: Assírio\&Alvim, 2014.

BAPTISTA, Abel Barros. O livro agreste. Ensaio de curso de literatura brasileira. Campinas: Ed. Unicamp, 2005.

BAPTISTA, Abel Barros. “Ortopedia do símile”. Colóquio Letras, n. 157-158, julho-dezembro 2000. Lisboa: Fundação Calouste Gulbenkian, p. 273-280.

COLÓQUIO LETRAS “Panorama Tipográfico. Homenagem a João Cabral de Melo Neto". Ns. 157-158. Julho-dezembro 2000. Vários autores. Lisboa: Fundação Calouste Gulbenkian.

EIRAS, Pedro. "Faca partilhada. Sophia de Mello Breyner Andresen e João Cabral de Melo Neto", 2011. In. http://web2.letras.up.pt/lyracompoetics 
FRIAS, Joana Matos. "Um olhar nítido como um girassol: João Cabral e Murilo Mendes”. Colóquio Letras, Ns. 157-158. Julho-dezembro 2000. Lisboa: Fundação Calouste Gulbenkian, p. 63-77.

LOURENÇO, Eduardo. Nau de Ícaro. São Paulo: Cia. das Letras, 2001. . Tempo e poesia. Lisboa: Relógio d’Água, 1974.

MARTELO, Rosa Maria. A forma informe. Lisboa: Assírio \& Alvim, 2010.

. Estrutura e transposição: invenção poética e reflexão metapoética na obra de João Cabral de Melo Neto. Fundação Engenheiro Antonio de Almeida, 1990 (dissertação de mestrado).

NETO, João Cabral de Melo. Poemas escolhidos. Sel. de Alexandre O’Neill, com prefácio de Alexandre Pinheiro Torres. Lisboa: Portugália Ed., 1963.

. Poesia completa (1940-1980). Prefácio de Óscar Lopes, “Das coisas e do seu avesso (sobre a poética de Melo Neto)". Lisboa: Imprensa Nacional- Casa da Moeda, 1986.

SARAIVA, Arnaldo. Modernismo brasileiro e modernismo português. Subsídios para o seu estudo e para a história das suas relações. Campinas: Ed. da Unicamp, 2004.

SOUSA, Carlos Mendes de. "Dar a ver o poema”. Posfácio. In: NETO, João Cabral de Melo. A educação pela pedra. Curso breve de literatura brasileira, vol. 12. Lisboa: Edições Cotovia, 2006.

SOUSA, Carlos Mendes de. "João Cabral ou o poema como epitáfio". Inimigo rumor, n. 14, 1․ Semestre de 2003. Rio de Janeiro: Viveiros de Castro Ed, São Paulo: Cosac \& Naify Ed., Lisboa: Cotovia, p. 156-169.

TAVARES, Maria Andresen de Sousa. "João Cabral de Melo Neto. Razão e 'serventia das ideias fixas'. Colóquio Letras, n. 157-158, julho-dezembro 2000. Lisboa: Fundação Calouste Gulbenkian, p. 257-271.

. Poesia e pensamento. Wallace Stevens, Francis Ponge, João Cabral de Melo Neto. Lisboa: Caminho, 2001.

Recebido para publicação em 06/08/2015 Aprovado em 28/09/2015

\section{NOTAS}

*Professora de Teoria Literária na USP. Escreveu o livro John Ashbery, um módulo para o vento e organizou textos poéticos de Ana Cristina Cesar em Antigos e soltos. Editou, com colegas, dois volumes sobre leituras de poesia e ficção. Defendeu a tese de livre-docência Poesia em risco (itinerários a partir dos anos 60). Publicou, com colegas, o livro Sereia de papel. Visões de Ana Cristina Cesar. 
2 Este artigo apresenta uma parte da pesquisa de pós-doutorado "A crítica literária portuguesa acerca da poesia brasileira moderna" realizada na Universidade Nova de Lisboa, sob supervisão do Prof. Nuno Júdice, em 2014. O trabalho inscreveu-se no âmbito maior do projeto integrado de pesquisa e cooperação científica "Crítica, poesia e contemporaneidade no Brasil e em Portugal: tendências e questões”, coordenado pelas Profas. Ida Alves e Celia Pedrosa, ambas docentes do Instituto de Letras da Universidade Federal Fluminense, em consórcio com a Universidade Nova de Lisboa, através da associação com o Prof. Nuno Júdice. O projeto foi financiado com bolsas pelo convênio CAPES-FCT, no período de 2013-2014.

3 Basta recordar, dentre tantos outros, nomes como José Osório de Oliveira (1900-1964), Vitorino Nemésio (1901-1978, professor, poeta e crítico literário, que escreveu tanto, em prosa e verso, sobre suas viagens ao Brasil, nos Poemas brasileiros, reunidos em 1972, ou em ensaios sobre poetas brasileiros, em crônicas sobre as cidades e as pessoas no Rio de Janeiro, na Bahia, em Ouro Preto, na caatinga e no Amazonas...), João Gaspar Simões (1903-1987), Adolfo Casais Monteiro (1908-1972, exilado no Brasil, professor na Unesp de Araraquara, com livros e ensaios importantes sobre o nosso modernismo e sobre Manuel Bandeira, dentre outros), Jorge de Sena (1919-1978, também exilado no Brasil pela ditadura salazarista, professor em várias instituições, com variados escritos sobre poetas brasileiros modernos), Óscar Lopes (1917-2013), Sophia de Mello Breyner Andresen (1919-2004), António Ramos Rosa (1924-2013, escreveu textos breves sobre Drummond e Cabral), David Mourão-Ferreira (1927-1996), Ruy Belo (1933-1978), Eduardo Prado Coelho (1944-2007), Eduardo Lourenço (1923, que foi professor durante um ano em Salvador, na Bahia, sempre atuante), dentre outros tantos. Mais recentes, hoje aposentados mas bastante ativos, Arnaldo Saraiva (dedicado em grande parte à docência de literatura brasileira na Universidade do Porto, tendo escrito estudos de vulto sobre Drummond e o modernismo, organizado congressos com resultados respeitáveis, entrevistado diversos escritores brasileiros, dentre eles o próprio Cabral), Fernando Cristovão (professor aposentado da Universidade Lisboa, com ensaios sobre Drummond, Cecília Meireles, em que os aproxima de poetas portugueses - embora a poesia não fosse o centro de seus variados estudos brasileiros), Margarida Maia Gouveia (professora também aposentada da Universidade dos Açores, com seu belo estudo sobre Cecília Meireles), Gastão Cruz (poeta e crítico bastante envolvido com a poesia brasileira contemporânea, seja através da revista Relâmpago, da qual agora é o editor responsável, seja através de recensões críticas) - para evocar a importância que a leitura interessada da poesia brasileira desfrutou sempre em Portugal...

4 Para compreender como a crítica portuguesa interpreta a relação entre Cabral e Sophia, é necessário conhecer a lenda ilustrada em O Cristo cigano, que Rosa Maria Martelo reproduz em seu prefácio ao livro, extraída de entrevista concedida pela própria Sophia, na qual narrava o episódio que, de certa forma, inspirou esta sequência de poemas. Cito: "[...] o pretexto deste poema foi a lenda do Cristo Cachorro que me contou em Sevilha, numa igreja de Triana, o poeta João Cabral de Melo Neto, a quem um cigano a tinha contado. Segundo esta lenda, a imagem chamava-se Cristo Cachorro, porque o modelo do escultor tinha sido um cigano de nome Cachorro que o próprio escultor havia apunhalado." (apud Martelo, 2014, p. 15, retirado do Jornal de Letras e Artes n. 17, 24/01/1962).

$5 \mathrm{O}$ extraordinário volume de ensaios coligidos neste número da Colóquio reúne não apenas os estudos dos críticos portugueses sobre os quais me deterei como, ao lado, textos históricos e inaugurais da crítica cabralina, como os famosos artigos inaugurais de Antonio Candido e Óscar Lopes, depoimento de Haroldo de Campos, leituras de Benedito Nunes, Luiz Costa Lima, Eucanaã Ferraz, Antonio Carlos Secchin, Marta Peixoto, João Alexandre Barbosa, dentre outros críticos, ao lado de cartas de Cabral para Clarice Lispector (apresentadas por Carlos Mendes de Sousa), poemas de Alexandre O'Neill, Armando Freitas Filho, Sebastião Uchoa Leite, e outros ainda... Enfim, é um tesouro para o amante de poesia.

6 Ao conferir ambos os textos, concluímos que há apenas alterações mínimas, de ordem estilística, de um para o outro.

7 O título é retirado de um verso de Alberto Caieiro, citado na epígrafe, que reproduzo: "O meu olhar é nítido como um girassol. [...] Creio no mundo como num malmequer,/ Porque o vejo." 
8 Baptista também investiga, em análise cuidadosa, a estrutura complexa desta obra, detendo-se em comentários interpretativos a respeito de dois poemas em particular, em sua "Segunda leitura: A educação pela pedra, de João Cabral de Melo Neto", capítulo de O livro agreste (2005).

9 "Comecei a senti-lo como um objeto estranho na minha poesia", diz a poeta para sua filha Maria Andresen Sousa Tavares, ao ser interpelada sobre o motivo de haver retirado o livro do conjunto de suas obras. Mas depois, voltou atrás da decisão, mesmo pressupondo a influência forte de Cabral no estilo dos poemas ("Nota à quinta edição de O Cristo cigano, 2014). 